Acta Universitatis Wratislaviensis • No 4055

Literatura i Kultura Popularna XXVII, Wrocław 2021

https://doi.org/10.19195/0867-7441.27.25

\author{
Maciej Sztąberek \\ ORCID: 0000-0003-2185-5246 \\ Uniwersytet Łódzki
}

\title{
Jak wywołać grozę? \\ Analiza porównawcza powieści i serialu Terror
}

Słowa kluczowe: horror, kino grozy, Ridley Scott, serial telewizyjny, wyprawa Franklina, Royal Navy

Keywords: horror movies, terror films, Ridley Scott, TV series, Franklin's lost expedition, Royal Navy

\section{Historia ekspedycji Franklina z 1845 roku jako inspiracja do stworzenia faction}

Edmund Burke w Dociekaniach filozoficznych o pochodzeniu naszych idei wzniosłości i piękna pisał: „Na ogół wydaje się, że aby cokolwiek uczynić bardzo wzniosłym, konieczna jest tajemniczość. Gdy znamy pełny wymiar niebezpieczeństwa, gdy możemy przyzwyczaić do niego oczy, przerażenie w znaczącej mierze ustępuje"1.

Najwyraźniej Dan Simmons oraz adaptujący jego powieść twórcy wyprodukowanego przez Ridleya Scotta serialu Terror ${ }^{2}$ — David Kajganich i Soo Hugh — kierowali się podobnym podejściem. Już sam wybór tematu implikuje tajemniczość, gdyż odnosi się do zdarzeń, które do dziś budzą kontrowersje oraz

${ }^{1}$ E. Burke, Dociekania filozoficzne o pochodzeniu naszych idei wzniosłości i piękna, przeł. P. Graff, Warszawa 1968, s. 65.

2 Terror(The Terror), AMC, USA 2018. 
domysły - mowa o brytyjskiej ekspedycji badawczej z 1845 roku do Arktyki, kierowanej przez admirała Johna Franklina, poszukującej słynnego Przejścia Północno-Zachodniego. Jego odkrycie otworzyłoby angielskiej żegludze drogę morską z Europy do Azji Wschodniej.

Wyprawa Franklina składała się z dwóch okrętów. Na pokładach obu jednostek wyruszyło łącznie 129 marynarzy ${ }^{3}$. Żaden z nich nie wrócił żywy, a ślad po ekspedycji oraz żaglowcach zaginą ${ }^{4}$. Dopiero w 2014 i 2016 roku udało się odnaleźć wraki okrętów 5 . Co ważne, ekspedycja była wyposażona w bardzo nowoczesny jak na tamte czasy sprzęt. Oprócz tego okręty zaopatrzono w rezerwy żywności, które miały wystarczyć załodze na trzy lata, w tym konserwy zaplombowane ołowiem. Ten, zamiast chronić żywność, dostawał się jednak do środka, co przyczyniło się do tragicznego finału ekspedycji. Był to zapewne także jeden z powodów, który skłonił zastępcę sir Johna Franklina — kapitana ${ }^{6}$ Francisa Croziera - do opuszczenia okrętów i pieszej wędrówki po lodzie aż do ujścia rzeki Back. Ponadto, według świadectw zamieszkujących tamte tereny Inuitów, członkowie załogi, aby przeżyć, dopuszczali się aktów kanibalizmu. Tego rodzaju doniesienia prowadziły tylko do coraz większej ilości spekulacji na temat losów członków ekspedycji. Ich śmierć ogłoszono dopiero po wielu wyprawach poszukiwawczych w tamte rejony. Jak zatem zginął admirał Franklin? Co dokładnie skłoniło Croziera do rozpoczęcia tak karkołomnej wyprawy? Co było głównym powodem śmierci wielu ludzi? Mimo upływu ponad 170 lat wciąż nie uzyskano dokładnych odpowiedzi na te pytania...

To właśnie tę lukę postanowili wykorzystać Dan Simmons oraz twórcy serialowej adaptacji ${ }^{7}$ jego powieści Terror (2007; wyd. pol. 2015) ${ }^{8}$. Pisarz, przygotowując się do tworzenia historii feralnej ekspedycji, oparł się na materiałach źródłowych pochodzących z epoki, na przykład dokumentacji marynarki wojennej, planach okrętów, relacjach z wypraw poszukiwawczych ${ }^{9}$ czy artefaktach odnale-

${ }^{3}$ HMS Terror ,,zamrożony w czasie”. Stynny okręt zostat zbadany, TVN24, https://bit. ly/2W206hp (dostęp: 30.12.2019).

${ }^{4}$ Ibidem.

5 K. Kowalski, Jak zginęli członkowie polarnej ekspedycji Johna Franklina, „Rzeczpospolita", https://bit.ly/3wMq31b (dostęp: 30.12.2019).

${ }^{6}$ Zarówno przy nazwisku Croziera, jak i Fitzjamesa będę używał stopnia „kapitan”, gdyż takie jest właściwe tłumaczenie tego stopnia oficerskiego. Określenie stosowane przez autora polskiego tłumaczenia tego utworu jest nieadekwatne, ponieważ stopień „komandor” jest współczesnym stopniem polskiej marynarki wojennej.

7 Warto wspomnieć, że serial Terror ma obecnie dwa sezony, lecz tylko pierwszy z nich jest zgodny z fabułą powieści. Akcja drugiego sezonu dzieje się 92 lata później w USA podczas II wojny światowej. Sezony nie są więc z sobą powiązane fabularnie. Na potrzeby tej pracy będę analizował wyłącznie pierwszy sezon serialu.

8 D. Simmons, Terror, przeł. J. Ochab, Czerwonak 2015.

9 Wszystkie źródła Dan Simmons wymienia w bibliografii na końcu powieści; zob. ibidem, s. $645-647$. 
zionych podczas ekspedycji ratunkowych poszukujących Franklina ${ }^{10}$. Szczególnie interesujące wydaje się wykorzystanie wielokrotnie wspominanej w Terrorze notatki z 25 kwietnia 1848 roku, sporządzonej na standardowym formularzu brytyjskiej Royal Navy przez kapitanów: Francisa Croziera oraz Jamesa Fitzjamesa, odnalezionej podczas wyprawy Francisa Leopolda McClintocka w 1859 roku. W powieści notatka sporządzana jest dwa razy — najpierw przez jednego z poruczników, który przed śmiercią w szponach monstrum zdążył spisać meldunek, że wszystko przebiega zgodnie z planem, później zaś obaj dowódcy okrętów nanieśli na niego korekty informujące o stracie admirała Franklina, innych osób oraz fatalnej sytuacji.

Wykorzystanie źródeł umożliwiło pisarzowi wykreowanie wiarygodnego świata przedstawionego, uzupełnionego o elementy fikcjonalne i fantastyczne. Jak zauważyła Maria Lindgren Leavenworth:

Legendy wokół osób (głównie mężczyzn), którzy udali się na krańce ziemi w imię eksploracji i tam przepadli bez wieści, rodzą możliwość fikcjonalizacji, szczególnie w przypadku występowania jakiejś luki w historii bądź braku znanych faktów na temat tego, co się faktycznie wydarzyło ${ }^{11}$.

Opisane przez Leavenworth zjawisko w anglojęzycznej terminologii określa się mianem faction. Może być ono rozumiane zarówno jako technika polegająca na rozmyciu fikcji i dokumentalnej relacji poprzez wprowadzenie do świata przedstawionego licznych faktograficznych dygresji ${ }^{12}$, jak i termin genologiczny, określający grupę utworów, w których ta technika występuje. Na przykład autor powieści Dzień Szakala (1972), Frederick Forsyth, twierdzi, że „Można zacząć powieść »na zimno«, przywołać realne wypadki i w ten sposób pobudzić ciekawość odbiorców, nie mówiąc im, czy mają do czynienia z prawdą czy fikcją. Tak dzieje się w podgatunku zwanym po angielsku faction i mieszającym oba wspomniane składniki"13. $\mathrm{Z}$ kolei Beth Herbert w swoim artykule poświęconym faction wskazuje za Franem Knightem, że faction to „fikcja historyczna z prawdziwymi postaciami, oparta na szczegółowych badaniach, z wyobrażonymi rozmowami i postaciami łączącymi historię"14. Podobną definicję formułuje Toni Bruce, przedstawiając ,faction i factionalizację jako metodę łączenia faktów z fikcją"15. Lois R. Kuznets zaś przez faction rozumie: „Fikcyjne dzieła pisane prozą, oparte wyłącznie na zebranych

10 Zdjęcia można znaleźć na końcowych stronach powieści Simmonsa.

11 M.L. Leavenworth, The Times of Men, Mysteries and Monsters: The Terror and Franklin's Last Expedition, [w:] Arctic Discourses, red. A. Ryall, J. Schimanski, H. Howlid Wærp, Newcastle upon Tyne 2010, s. 199; jeśli nie podano inaczej, przeł. M.S.

12 D. Jones, za: M. Kraska, Na tropie Szakala. Gry i konwencje political fiction, Gdańsk 2003.

13 F. Forsyth, Upiór Manhatanu, przeł. W. Nowakowski, Warszawa 1999, s. 19.

${ }^{14}$ F. Knight, za: B. Herbert, When English Meets History: Exploring the Faction Genre through Action Learning, „Literacy Learning: The Middle Years” 20, 2012, nr 3, s. 87.

15 T. Bruce, The Case for Faction as a Potent Method for Integrating Fact and Fiction in Research, [w:] Innovations in Narrative and Metaphor - Methodologies and Practices, red. S. Farquhar, E. Fitzpatrick, Auckland 2019, s. 57. 
przez autora faktach bądź prawdziwych historiach życia według ich autorów"16. Oliver Conolly i Bashshar Haydar uważają natomiast, że dokładność faktograficzna charakterystyczna dla faction nie świadczy o wartości literackiej i właśnie dlatego ich zdaniem traktowanie faction jako gatunku zawodzi ${ }^{17}$. Badacze ci przekonują jednak, że:

W przeciwieństwie do fikcji faction ma na celu uchwycenie faktów na temat życia osób z krwi i kości oraz prawdziwych wydarzeń, które miały miejsce w ich życiu. Nie musi to oznaczać, że faction nie może dążyć do uchwycenia faktów na temat typów postaci, ich moralności i tym podobnych. Jednak cechą wyróżniającą faction jest to, że ma ona na celu dbałość o dokładność faktów dotyczących stanów rzeczy konkretnych osób, grup, ich cech czy faktów odpowiadających na pytania kto, co, kiedy ${ }^{18}$.

Choć definicje te nieco się różnią, niezależnie od tego, czy przyjmiemy, iż jest to technika konstrukcji opowieści, czy też podgatunek literacki, udowadniają one, że podstawowym warunkiem zaistnienia faction jest wymieszanie wydarzeń prawdziwych z fikcyjnymi tak, aby łączyły się w całość. Trudno jednoznacznie ocenić, czy Terror Simmonsa można uznać za przykład podgatunku faction, gdyż w swoich utworach pisarz często łączy z sobą różne gatunki. W tym przypadku czytelnicy mają do czynienia z fuzją powieści historycznej, horroru i fantastyki ${ }^{19}$. Faction wydaje się więc raczej techniką, swego rodzaju narzędziem, które Simmons wykorzystał, tworząc tę gatunkową hybrydę. Twórcy serialu postanowili pozostać wierni literackiemu pierwowzorowi i ograniczyli się tylko do skondensowania fabuły, aby zaadaptować ją na potrzeby dziesięcioodcinkowego serialu.

W powieści Simmons posługuje się techniką faction, zachowując przede wszystkim autentyczność postaci. Zarówno admirał John Franklin, jego kapitanowie Francis Crozier i James Fitzjames, jak i inni oficerowie oraz członkowie załogi są postaciami historycznymi. Pisarz ich nazwiska zaczerpnął z list werbunkowych bądź zachowanej korespondencji prywatnej ${ }^{20}$. Technika faction polegała przede wszystkim na zbudowaniu osobowości postaci oraz odtworzeniu przebiegu zdarzeń, które miały miejsce w trakcie wyprawy, opierając się na danych histo-

${ }^{16}$ L.R. Kuznets, Fiction, Faction, and Formula in the Regional Novels of Lois Lenski, „Children's Literature Association Quarterly" 1982, s. 98.

17 O. Conolly, B. Haydar, The Case Against Faction, „Philosophy and Literature” 32, 2008, nr 2, s. 348.

18 Ibidem.

19 Nie używam w kontekście powieści i serialu Terror pojęcia ,thriller” ze względu na to, że w fabułach obydwu utworów występują czynniki paranormalne, które w thrillerze z zasady nie pojawiają się, są one natomiast konstytutywne dla horroru. Ponadto, za Rafałem Syską, thriller traktuję jako formułę gatunkową nadrzędną w stosunku do innych gatunków i - jak wskazuje z kolei Kamila Żyto - mającą cechy wspólne ze strukturą przestrzenną, jaką jest labirynt - typowe miejsce akcji wielu powieści gotyckich, a także filmowych horrorów. Dodatkowo zarówno Syska, jak i Żyto uznają, że dreszczowiec pasożytuje na różnych gatunkach, a nie stanowi samoistnego gatunku. Zob. eadem, Strategie labiryntowe w filmie fikcji, Łódź 2010, s. 71-73, R. Syska, Thriller jako gatunek, [w:] Wokót kina gatunków, red. K. Loska, Kraków 2001, s. 79, 81.

${ }^{20}$ D. Simmons, op. cit., s. 647. 
rycznych. Część wydarzeń mających miejsce przed rozpoczęciem wyprawy, jak choćby objęcie przez Franklina funkcji gubernatora Ziemi Van Diemena (obecnej Tasmanii) i związany z tym konflikt polityczny, również są prawdziwe ${ }^{21}$. Ponadto w celu wywołania wrażenia realizmu duża część rozdziałów, które zawsze są napisane z perspektywy konkretnej postaci, zawiera informacje na temat położenia geograficznego bohaterów oraz datę wpisu, dzięki czemu autorowi udało się utrzymać powieść w stylistyce dziennika pokładowego bądź też prywatnych pamiętników postaci ${ }^{22}$.

Kolejnym szczególnie ciekawym przykładem stylizacji są wpisy doktora Harry'ego Goodsira zawarte w rozdziałach pisanych z jego spojrzenia. W przeciwieństwie do zwykłej treści rozdziałów w formie narracji trzecioosobowej, jego zapiski wyróżnione są kursywą i napisane z perspektywy pierwszoosobowej. Bardzo często składają się one na cały rozdzial ${ }^{23}$. Opisy te wraz z rozwojem wydarzeń stają się coraz mroczniejsze. Bohater jest lekarzem okrętowym, w związku z czym $\mathrm{w}$ jego notatkach pojawia się coraz więcej wspomnień związanych z makabrycznymi okolicznościami zgonów członków załogi. Z kolei twórcy serialu posłużyli się innym chwytem. Realistycznie wyglądające zdjęcia w połączeniu z drobiazgowo przygotowaną scenografią i kostiumami zgodnymi z realiami historycznymi wywołują silne wrażenie autentyczności. Niektóre ujęcia przypominają fotografie oraz obrazy czy też ilustracje z epoki. Na uwagę zasługuje fakt, że statki wyglądają wiarygodnie, a to dzięki temu, iż zostały zbudowane od podstaw w jednej z hal zdjęciowych ${ }^{24}$, a ich wnętrze zostało wyposażone w pieczołowicie przygotowane

${ }^{21}$ Franklin, Sir John, [hasło w:] Dictionary of Canadian Biography, https://bit.ly/3iwcsWq (dostęp: 30.12.2019).

${ }^{22}$ Na przykład: „5 CROZIER 7005’ szerokości geograficznej północnej, 98²3’ długości geograficznej zachodniej. 9 listopada 1847” - D. Simmons, op. cit., s. 54. Tekst oryginału: „5 CROZIER. Lat. 70-05' N., Long 98-23' W. 9. November, 1847' — idem, The Terror, New York 2007.

23 Dobrym przykładem jest chociażby fragment: „Z prywatnego dziennika doktora Harry’ego D.S. Goodsira: 11 kwietnia 1845. W liście do mojego brata napisałem dzisiaj: »Wszyscy oficerowie mają ogromną nadzieję, że uda im się przepłynąć i że pod koniec przyszłego lata będą już na Pacyfiku«. Wiem, że ktoś mógłby uznać to za egoizm, ale osobiście żywię nadzieję, iż minie trochę więcej czasu, nim nasza wyprawa dotrze do Alaski, Rosji, Chin i ciepłych wód Pacyfiku. Choć komandor [sic!] sir John Franklin powierzył mi stanowisko asystenta lekarza pokładowego, w gruncie rzeczy nie jestem zwykłym lekarzem, lecz doktorem nauk medycznych i muszę wyznać, że podczas tej podróży pragnąłbym zostać chociaż początkującym przyrodnikiem" - ibidem, s. 48. Tekst oryginału: „From the private diary of Doctor Harry D.S. Goodsir: 11 April, 1845. In the letter to my brother today I wrote: »All the officers are in great hopes of making the passage and hope to be in the Pacific end of next summer«. I confess that, however selfish it is, my own hope for the expedition is that it make take us a bit longer to reach Alaska, Russia, China and warm waters of the Pacific. Although trained as an anatomist and singed on by Captian Sir John Franklin as a mere assistant surgeon, I am in Truth, no mere surgeon but a Doctor, and I confess further that as amateurish as my attempts may be. I hope to become something of a Naturalist of this toyage".

24 K. Han, The Terror, TV's Scariest New Series, Isn't Really a Horror Story, „Vanity Fair”, https://bit.ly/3wSPjm8 (dostęp: 30.12.2019). 
umeblowanie i rekwizyty - przedmioty stosowane na prawdziwych okrętach ${ }^{25}$. Co więcej, wszelkie ruchy naśladujące lód wgniatający kadłub okrętów i wypychające go do góry również zostały zaaranżowane, do tego stopnia, że obecni na pokładzie aktorzy w efekcie zaskoczenia rzeczywiście tracili równowagę, co miało wpłynąc na realizm ich zachowań ${ }^{26}$.

Dzięki detaliczności rekonstrukcji statków aktorzy mogli wchodzić w interakcję z wyposażeniem okrętów, kamera zaś pokazywała ich wnętrze z tak wielu perspektyw, iż bardzo łatwo można wyobrazić sobie układ pomieszczeń. W rezultacie Terror przypomina superprodukcję historyczną na miarę takich filmów jak chociażby Wojna i pokój (1967). Dodatkowo twórcy zdecydowali się użyć różnego rodzaju filtrów nałożonych na obraz, dzięki którym uzyskali ciemną kolorystykę oscylującą głównie wokół koloru niebieskiego. Zimne zabarwienie w połączeniu ze scenami nagranymi nocą oraz efektami specjalnymi, na przykład w postaci śnieżycy, wzmogły wrażenie autentyzmu i podkreśliły realność zagrożenia.

Można zatem stwierdzić, że zarówno w przypadku powieści, jak i serialu Terror twórcy posłużyli się techniką faction, aby wywołać u odbiorcy intensywne wrażenie realności przedstawianych wydarzeń. To, że dotyczą one historycznej wyprawy polarnej, której fiaska dokładne powody do dziś nie są pewne, tworzy pole do różnego rodzaju spekulacji, a w konsekwencji stymuluje powstawanie fantazji na ten temat. Połączenie faktów historycznych za sprawą techniki, jaką jest faction, z elementami fikcjonalnymi należącymi do horroru czy fantastyki przyczynia się nie tylko do stworzenia atrakcyjnej w odbiorze formy, lecz także do intensyfikacji atmosfery grozy. Im bardziej zagrożenie zdaje się realne i prawdopodobne, tym większy strach wywołuje. Twórcy obydwu utworów świadomie wykorzystali ten mechanizm w celu nie tyle zobiektywizowania historii, ile pogłębienia atmosfery grozy. Paradoksalnie więc to faction, a nie tylko fikcjonalizacja zostaje wykorzystane w służbie gatunkowych konwencji.

\section{Elementy grozy w powieści i serialu Terror}

Można także zaryzykować stwierdzenie, że gatunkiem dominującym zarówno w przypadku powieści, jak i serialu jest horror. Jak zauważa Anna Gemra: „Korzeni horroru jako gatunku w kształcie, w którym dziś spotykają się z nim odbiorcy w literaturze czy filmie, poszukiwać należy przede wszystkim w powieści gotyckiej (romansie gotyckim)"27. W powszechnym użytku przyjęła się zaś nazwa „powieść grozy”. Jak zauważa jednak wspomniana badaczka:

25 Why Tobias Menzies and Jared Harris Always Do Historic Movies?, YouTube, [3.00-4.00], https://bit.ly/3hNah1I (dostęp: 30.12.2019).

26 K. Han, op. cit.

27 A. Gemra, Od gotycyzmu do horroru: wilkołak, wampir i monstrum Frankensteina w wybranych utworach, Wrocław 2008, s. 5. 
Wraz ze wzrostem popularności nowego medium, jakim był film, coraz częściej używano nazwy ,horror”, początkowo jako wygodnego, powszechnie zrozumiałego, obiegowego pojęcia, charakteryzującego tę grupę filmów, w których dominantę artystyczną stanowiła groza. [...] W świadomości przeciętnego odbiorcy pojęcie to zakorzeniło się na tyle, że także wydawcy zaczęli zachęcać do lektury utworów grozy, używając słowa „horror”, ponieważ było zrozumiałe dla klientów. Obecnie nazwy: ,powieść grozy”, „literatura grozy”, ,film grozy" i ,horror" są stosowane wymiennie, choć nie ma jednomyślności badaczy co do tego, czy ich zakresy znaczeniowe się pokrywają. Bodaj najczęściej używa się przeniesionego z filmoznawstwa terminu ,horror"; okazał się on wygodny, a przy tym unaocznia fakt wzajemnego wpływu tekstów literackich i filmowych, ich interakcji i koegzystencji w kulturze oraz pozwala na rozpatrywanie ich we wzajemnych powiązaniach ${ }^{28}$.

Ze względu na to, że zarówno wspomniane teksty literackie, jak i filmy mają wspólną dominantę artystyczną, jaką jest groza, zasadne — ale i wygodne - wydaje się używanie terminu ,horror”. Zwłaszcza że w obu przypadkach odbiorca ma do czynienia z wieloma cechami wspólnymi. Różni je tylko sposób przedstawienia historii oraz wywoływania grozy, co wynika ze specyfiki obu mediów. Z tego względu w dalszej części pracy będę się posługiwał terminem ,horror”. Magdalena Kamińska twierdzi, że należy on do nadrzędnej kategorii, jaką jest fantasty$\mathrm{ka}^{29}$. Definiuje ją jako

Przeciwieństwo realizmu, co oczywiście nie wyczerpuje długiej listy jej odczytań, szczególnie licznych w polu literaturoznawstwa. Za Tzvetanem Todorovem uznaje się często, że fantastyczność oznacza stan niepewności i wahania, którego doświadcza materialistycznie nastawiony człowiek stający wobec zjawiska niewytłumaczalnego, które może okazać się nadprzyrodzonym. Idąc za myślą Rogera Caillois — przyjąć zaś można, że korpus tekstów fantastyki stanowi grupa utworów, w których element nadprzyrodzony rozbija spójność świata przyrodzonego. Jak dodaje Krzysztof Loska — w przypadku baśni ów czynnik nadprzyrodzony przynależy do świata naturalnego, w science fiction poszukuje się (pseudo)naukowego wyjaśnienia tego, co pozornie wygląda na niezrozumiałe i być może nadprzyrodzone, zaś w horrorze to, co nadprzyrodzone, pozostaje sobą i jako takie agresywnie atakuje to, co przyrodzone, codzienne, normalne, oswojone, rzeczywiste ${ }^{30}$.

W przypadku Terroru zdecydowanie mamy do czynienia z horrorem, albowiem elementy nadprzyrodzone stopniowo niszczą wszystko to, co należy do porządku świata codziennego bohaterów.

Przed przystąpieniem do analizy elementów grozy w powieści i serialu Terror warto poświęcić kilka słów elementom, które przyczyniają się do wywoływania grozy. Jak pisze Bożena Płonka-Syroka:

Groza wywoływana jest zwykle przez czynniki kulturowe, które nadają określony rodzaj interpretacji otaczającym nas zdarzeniom. Poza bowiem tymi, które dotykają nas pod względem cielesnym, wiążąc się na przykład z doświadczanym w sposób bezpośredni znacznego stopnia bólem lub też strachem przed nim, wszystkie inne zjawiska i zdarzenia, aby wy-

28 Ibidem, s. 6.

29 M. Kamińska, Upiór w kamerze: zarys kulturowej historii kina grozy, Poznań 2016, s. 1617.

30 Ibidem.

Literatura i Kultura Popularna XXVII, Wrocław 2021

(C) for this edition by CNS 
wołać w nas emocję grozy, muszą być przez nas wcześniej w jakiś sposób rozpoznane, wyodrębnione $\mathrm{z}$ tła jako groźne i w ten sam sposób rozumiane. To nie samo zdarzenie lub zjawisko automatycznie wywołuje w nas poczucie grozy, ale jego kulturowa interpretacja, nadająca ramy naszym spostrzeżeniom ${ }^{31}$.

Czynniki kulturowe są zatem kluczowe do interpretacji danego zdarzenia i uznania go przez odbiorcę za groźne bądź nieszkodliwe. Znaczące wydają się tutaj proporcje. $Z$ jednej strony dane zdarzenie czy zjawisko musi być więc jednocześnie trochę znane odbiorcy, aby mógł je rozpoznać jako coś niebezpiecznego (w Terrorze służy temu faction), a z drugiej — musi być wystarczająco nieznane, aby wzbudzić w nim lęk wynikający z braku wiedzy na temat tego, jak sobie $\mathrm{z}$ tym zagrożeniem poradzić.

Ksenia Olkusz twierdzi z kolei, że:

Twórcy bardzo często posługują się mechanizmami kontrarności, budując wizje w oparciu o opozycję pomiędzy tym, co odbiorcy uznają za modelowe, a tym, co spatologizowane, dążąc do wyeksponowania takich elementów, które ulegają zaburzeniu, atrofii czy degradacji. W ten sposób - poprzez szczególne odwrócenie porządku — dokonuje się proces budowania nastroju zagrożenia, skorelowany z niezwykle istotnym komponentem lękotwórczym, jakim jest suspens. Teksty grozy konfrontują więc odbiorców z wielopoziomowym zbiorem rozmaitych problemów nękających zbiorowości ludzkie ${ }^{32}$.

Pogląd tej badaczki koreluje więc bezpośrednio z koncepcją Płonki-Syroki. Aby bowiem można było skonfrontować odbiorców z problemami nękającymi ich zbiorowości, zagrożenie to musi być im poniekąd znane. Tym tropem poszedł także autor powieści Terror - Dan Simnons, który oparł się na kilku elementach, które posłużyły mu do zbudowania atmosfery grozy. Należą do nich:

- izolacja,

- człowiek,

- trudne warunki pogodowe i terytorialne,

- choroba,

- potwór.

Wszystkie te elementy są w jakiś sposób znane odbiorcom, ponieważ od wieków towarzyszą człowiekowi, utrudniając jego egzystencję. Wyjątkiem może być jedynie potwór. Stanowi on jednak uosobienie lęku ludzkości dotyczącego potęgi natury.

Twórcy serialu poszli w ślady pisarza. Modyfikacje dotyczą relacji pomiędzy niektórymi postaciami oraz rewizji ich funkcji w przebiegu akcji. Niektórzy bohaterowie zostali usunięci, rolę innych umniejszono. Wszystkie elementy grozy należące do warstwy fabularnej zostały jednak zachowane. Zmienił się wyłącznie sposób ich ewokowania jako rezultat wykorzystania środków wyrazowych innego medium.

31 B. Płonka-Syroka, Wstęp, [w:] Groza. Społeczno-kulturowe mechanizmy kreowania emocji, red. B. Płonka-Syroka, M. Szymczak, Wrocław 2010, s. 7.

32 K. Olkusz, Gotyckie światy współczesnej grozy, [w:] Światy grozy, Kraków 2016, s. 21. 
Rozwiązaniem, na które warto szczególnie zwrócić uwagę w kontekście budowania grozy, jest już sama czarno-biała czołówka serialu. Pokazuje ona w dużym przyśpieszeniu, jak statki Terror i Erebus zostają uwięzione w lodzie i wykrzywione pod jego naporem. Następnie pojawiające się postaci albo są ukazywane pod warstwą lodu, albo - również w przyśpieszonym tempie — ich ciała ulegają rozkładowi. Można więc pokusić się o stwierdzenie, że zabieg ten jest zapowiedzią sposobów służących wywołaniu grozy wykorzystanych później.

\section{Izolacja}

Pierwszym z rzeczonych sposobów jest motyw izolacji głównych bohaterów. Ponieważ zarówno Erebus, jak i Terror utknęły w paku lodowym, ich załogi nie mogą ani wrócić do domu, ani uciec przed zagrożeniem. W dodatku już same nazwy okrętów wydają się znaczące - Erebus to grecki bóg opiekujący się najciemniejszą częścią Hadesu; konotacje zaś słowa „terror” są oczywiste. Zamarznięty akwen Archipelagu Arktycznego staje się naturalną i symboliczną pułapką, która odcina możliwość otrzymania pomocy z zewnątrz. Tymczasem statek, zwłaszcza żaglowy, kojarzy się z wolnością żeglugi po bezkresie mórz i oceanów. W Terrorze okręty zamieniają się jednak w uziemione i oblężone twierdze, które zapewniają marynarzom tylko namiastkę bezpieczeństwa. Ze względu na to, że ekspedycja ma charakter badawczy, żaglowce zostały pozbawione ciężkiego uzbrojenia w postaci armat czy moździerzy. Załogi mają do dyspozycji jedynie broń palną.

Warto podkreślić, że izolacja nabiera w tym przypadku także innego wymiaru - nie tylko odcina załogi okrętów od pomocy, ale też od wymiaru sprawiedliwości i władzy państwowej. Czynnik ten ma więc znaczący wpływ zarówno na morale członków ekspedycji, jak i ich poczucie przyzwoitości. Tym, co powstrzymuje ludzi od łamania norm moralnych i rozkazów, są dyscyplina, tradycja i hierarchia panujące $\mathrm{w}$ marynarce wojennej — wpajane marynarzom od pokoleń za pomocą różnego rodzaju kar. Elementem tradycji jest z pewnością wydawanie marynarzom grogu, którego brak mógłby przyczynić się do wybuchu buntu. Z obawy przed nim zwykli maci nie mają dostępu do broni palnej. W przypadku izolacji ciężar utrzymania dyscypliny spoczywa zatem na dowódcach okrętów, którzy dzięki wykształceniu i wiedzy powinni wiedzieć, co robić, choć większość z nich nie znalazła się wcześniej w tak trudnych okolicznościach. Jeśli dodamy do tego konflikty osobiste między głównodowodzącym Franklinem a jego zastępcą Crozierem, sytuacja jeszcze bardziej się skomplikuje. Izolacja ma bowiem wpływ na psychikę bohaterów, którzy różnie radzą sobie z samotnością i mogą być zagrożeniem dla siebie i innych.

W serialu, aby wywołać wrażenie izolacji, twórcy wykorzystali przede wszystkim nietypowe kadrowanie. Do pokazywania skutych lodem okrętów i ich otocze- 
nia wykorzystano szerokokątne obiektywy, dzięki którym udało się ukazać otaczający bohaterów bezkres skutego lodem lądu. Od brzegu do brzegu widać jedynie śnieżnobiałe przestrzenie — żadnych miast, roślin czy zwierząt, wyłącznie skarpy lodu. W tym celu wykorzystano także kadrowanie z perspektywy ptasiej w szerokich planach. Uwięzione i umiejscowione w centrum kadru okręty przypominają pozostawione na lodzie zabawki... Zastosowanie takich ustawień kamery w scenach rozgrywających się podczas nocy polarnej, kiedy kształty żaglowców ledwo odróżniały się od ciemnoniebieskiej masy lodu, wyłącznie dzięki rozstawionym na pokładzie latarniom, przynosi jeszcze mroczniejszy efekt. Można odnieść wrażenie, że otaczająca bohaterów przestrzeń stopniowo pochłania nawet ich drewniane twierdze. Ciemność na zewnątrz, rozświetlana jedynie dzięki zorzy polarnej, jest kolejnym ze sposobów budowania atmosfery izolacji.

Drugą metodą podkreślania izolacji bohaterów jest wykorzystanie wnętrz samych okrętów. Drewniane konstrukcje kadłubów, choć mają chronić marynarzy przed zewnętrznymi zagrożeniami oraz zimnem, często przypominają zbite $z$ desek więzienie. Przestrzenie umiejscowione pod pokładem są ciemne i ciasne. W dodatku bardzo często ukazywane są za pomocą perspektywy jedno- lub dwupunktowej oraz głębi ostrości, w wyniku czego drewniane korytarze wydają się wąskie i długie. Ciemna kolorystyka mebli i ścian sprzyja budowaniu klaustrofobicznej atmosfery. Choć na początku serialu wnętrza okrętów zdają się emanować ciepłem, po pewnym czasie one również stają się coraz zimniejsze. Dzięki zastosowanym środkom stylistycznym twórcom udało się oddać obecne w powieści wszechogarniające wrażenie izolacji.

\section{Czlowiek}

Drugim elementem, który zagraża bohaterom, jest inny człowiek. Kluczowa jest tutaj postać mata uszczelniacza Corneliusa Hickeya, który od samego początku jest ukazywany jako postać o wątpliwej moralności. W odpowiednich do tego okolicznościach staje się coraz bardziej bezduszny i posuwa się do coraz większych niegodziwości. Z czasem okazuje się równie niebezpieczny co polujące na bohaterów monstrum, stanowi zagrożenie wewnętrzne, działa niczym choroba autoimmunologiczna, manipuluje marynarzami i stopniowo nakłania ich do buntu. Postać ta staje się źródłem grozy, choć w tym przypadku strach jest racjonalny i uzasadniony. W dodatku za sprawą namów Hickeya kolejni marynarze zaczynają dopuszczać się aktów kanibalizmu na swoich niedawno zmarłych bądź bliskich śmierci kolegach. Wszelkie tego typu zachowania w sposób naturalny wywołują uczucie wstrętu.

Interesujące wydaje się tu podejście twórców serialu do roli człowieka i potwora w procesie budowania atmosfery grozy. Znaczenie monstrum, choć podobne względem powieści, zostało jednak okrojone. Dużo większym zagrożeniem 
od niego stają się ludzie, a zwłaszcza wspomniany wcześniej mat Hickey, który zdaje się potworniejszy i bardziej nikczemny niż potwór, o czym może świadczyć fakt, że na końcu serialu, po pożarciu mata, bestia pochłania jego duszę, a następnie umiera.

Atmosferę grozy wokół Hickeya udało się osiągnąć przede wszystkim dzięki kreacji aktorskiej wcielającego się w niego Adama Nagaitisa. Postać ta w jego wykonaniu jest wyjątkowo charyzmatyczna, a jednocześnie dwulicowa i groteskowa - za sprawą pozornej przymilności. Bohater wielokrotnie obdarza swoich przeciwników nieszczerym, złowrogim, wręcz sardonicznym uśmiechem. Jego niezwykle ekspresyjna mimika (zwłaszcza pewna osobliwa mina, uzyskiwana poprzez wypychanie językiem policzka) w połączeniu ze stosunkowo drobną budową przyczyniły się do wykreowania postaci w równym stopniu charakterystycznej co niebezpiecznej. Ponadto umiejętność manipulacji oraz grania na ludzkich emocjach uczyniły z Hickeya postać szczególnie nieprzewidywalną. Poczucie grozy związane $\mathrm{z}$ tym bohaterem jest znacznie bardziej wiarygodne niż w przypadku potwora. Hickey przypomina psychopatę, a zatem typ osobowości o skłonnościach dobrze znanych i wielokrotnie wykorzystywanych w rozmaitych tekstach kultury.

\section{Trudne warunki pogodowe i terytorialne}

Trzecim elementem służącym do budowania nastroju grozy są same trudne warunki pogodowe i terytorialne. Członkowie ekspedycji muszą zmagać się zarówno z nieustającym mrozem, jak i długotrwałą ciemnością nocy polarnych. W trakcie lata polarnego stykają się zaś z oślepiającą jasnością, która utrudnia im zauważenie polującego na nich potwora. Oprócz tego życie marynarzy komplikują gradobicia i wyładowania atmosferyczne. Co ciekawe, geograf Grzegorz Rachlewicz w posłowiu do polskiego wydania Terroru zauważa:

W tym wszystkim tylko jeden element nie znajduje potwierdzenia w rzeczywistości popartej obserwacjami, nie tylko z punktu widzenia opisywanych czasów, ale także dzisiejszej wiedzy, i nie chodzi tu o mityczne stwory dziesiątkujące załogi statków. Wielokrotnie podczas peregrynacji w okolicach Wyspy Króla Williama bohaterowie mają do czynienia z burzami i wyładowaniami atmosferycznymi siejącymi wśród nich postrach i zagładę. Obszary polarne, z natury procesów atmosferycznych, są wolne od tych zjawisk. Burze z piorunami są tam wielką rzadkością. Podczas gdy w środkowej Kanadzie notuje się około 15 dni z burzami rocznie, na Nowej Funlandii już zaledwie 5, a wyspy arktyczne są praktycznie ich pozbawione. Pewien wzrost liczby burz jest związany ze zmianami klimatycznymi i większą niestabilnością procesów fizycznych w atmosferze, ale jest to obserwowane dopiero współcześnie ${ }^{33}$.

Powstaje pytanie, dlaczego Danowi Simmonsowi potrzebne były burze, skoro tak wiele niesprzyjających czynników już występuje w tym rejonie. Być może odpowiedź daje koncepcja Edmunda Burke’a, który wśród elementów świadczą-

33 G. Rachlewicz, Postowie, [w:] D. Simmons, op. cit., s. 650.

Literatura i Kultura Popularna XXVII, Wrocław 2021

(C) for this edition by CNS 
cych o wzniosłości wymienił moc, rozumianą jako potężna i niszczycielska siła ${ }^{34}$. Jak pisał: ,gdziekolwiek znajdujemy siłę i w jakimkolwiek świetle oglądamy moc, zawsze spostrzegamy wzniosłość nieodłączną od grozy, zaś pogardę towarzyszącą sile podległej i nieszkodliwej”35. Czy do takich objawów niszczycielskiej mocy nie należą właśnie wyładowania atmosferyczne? Innym elementem wymienianym w kontekście wzniosłości jest brak. Według brytyjskiego filozofa „wszystkie ogólne wyobrażenia braku znamionuje [sic!] wielkość, wszystkie bowiem budzą trwogę - pustka, ciemność, samotność i cisza" ${ }^{36}$. Każdy z nich został wykorzystany w Terrorze. Dzięki temu Simmons przedstawił obszar arktyczny jako jeszcze bardziej nieprzyjazny słabym i w wielu przypadkach niewinnym i bezbronnym w obliczu sił natury ludziom.

W serialu twórcy, chcąc oddać trudne warunki panujące na Archipelagu Arktycznym, wykorzystali przede wszystkim elementy scenograficzne oraz technologię CGI. Kostiumografowie uszyli mundury na wzór tych, jakie noszono w brytyjskiej Royal Navy w czasach wiktoriańskich, jak również stroje Inuitów, które imitowały odzienia rzeczywiście noszone przez ludność zamieszkującą tamte tereny. Zaspy śnieżne, pokrywa lodowa, zorza polarna na niebie, choć wyglądają bardzo realistycznie, zostały wykreowane za pomocą $\mathrm{CGI}^{37}$. Większość scen rozgrywających się na zewnątrz została nakręcona w hali zdjęciowej w Budapeszcie oraz na chorwackiej wyspie Pag, która imitowała Ziemię Króla Williama ${ }^{38}$. Żadnej ze scen nie nagrano zatem na Archipelagu Arktycznym. Producent serialu Ridley Scott w trakcie zdjęć użył dokładnie tych samych metod i technologii, jakie wykorzystał, realizując sceny dziejące się na Marsie w filmie Marsjanin (2015) ${ }^{39}$. Ponadto sekwencja, w której jeden z podoficerów schodzi pod wodę, aby usunąć lód blokujący silnik okrętu, również została nakręcona dzięki wspomnianej technologii. To właśnie dzięki nowoczesnym metodom manipulacji obrazem oraz pieczołowicie przygotowanej scenografii i kostiumom twórcom serialu udało się oddać warunki, jakie opisał Dan Simmons.

\section{Choroba}

Czwartym elementem budzącym grozę w Terrorze jest c h o r o b a, wywołana źle zakonserwowanym jedzeniem oraz brakiem świeżego pożywienia, zwłaszcza mięsa. Ze względu na trudne warunki pogodowe i sezon zimowy zwierzęta nie pojawiają się bowiem w okolicy okrętów. Po pewnym czasie marynarze są zatem

34 E. Burke, op. cit., s. 72-80.

35 Ibidem, s. 75.

36 Ibidem, s. 80-81.

37 B. Travers, The Terror' Was Not Shot Outside - It's Almost Entirely Visual Effects, IndieWire, https://bit.ly/2VW4yOx (dostęp: 30.12.2019).

38 Ibidem.

39 Marsjanin (The Martian), reż. R. Scott, USA-Wielka Brytania 2015. 
skazani wyłącznie na jedzenie z puszek. Bohaterowie są więc z każdym dniem coraz bardziej wycieńczeni i reagują rozdrażnieniem na bodźce dźwiękowe. Nikt z członków załogi nie może się uchronić przed chorobą. Stopniowo dotyka ona każdego, zarówno marynarzy, jak i uprzywilejowanych oficerów. Jednym z bardziej przerażających, a zarazem obrazujących grozę całej sytuacji momentów jest scena, w której kapitan Fitzjames zaczyna przegrywać walkę z chorobą:

Komandor Fitzjames cierpiał straszliwe katusze. Nieustające nudności, wymioty i biegunka oraz okropne skurcze sprawiały, że ten dzielny i silny mężczyzna zwijał się w kłębek i krzyczał z bólu. [...] Tego samego dnia, a właściwie w nocy, komandor powiedział mi, że ma kłopoty z przełykaniem i nieustannie czuje suchość w ustach. Wkrótce potem zaczął chrapliwie oddychać i nie mógł już mówić. Nim wstał dzień, paraliż objął ręce komandora, tak, iż nie mógł już nawet dłużej pisać. [...] I tak po kolei odchodzili od nas kolejni chorzy, jednak po niemal jednoczesnej śmierci porucznika LeVesconte'a i szeregowca Pilkingtona pod koniec drugiego tygodnia wędrówki nastał długi okres, podczas którego nikt nie umarł. Ludzie zaczęli wierzyć, że ci naprawdę chorzy już poumierali, a zostali tylko silni. Nagła zapaść komandora Fitzjamesa przypomniała nam, że wszyscy z dnia na dzień robimy się coraz słabsi. Tak naprawdę nikt spośród nas nie jest już silny ${ }^{40}$.

Zacytowany fragment dobrze oddaje dramatyzm sytuacji, w której śmierć nikogo nie oszczędza, a choroba jest w tym przypadku wrogiem wewnętrznym, który paradoksalnie zbiera dużo większe żniwo niż warunki pogodowe.

W serialu została ona ukazana mniej dramatycznie niż w powieści, a jej objawy zewnętrzne mocno ograniczono. Problemy zdrowotne bohaterów serialu objawiają się krwawieniem dziąseł, otwieraniem się ran i licznymi siniakami czy krwiakami, problemami z poruszaniem się, mówieniem, a w konsekwencji z przełykaniem i oddychaniem. Efekty udręki cielesnej bohaterów są widoczne dzięki odpowiedniej charakteryzacji twarzy postaci, które wyglądają na wyczerpane ich policzki są zapadnięte, skóra brudna i świecąca od potu, a usta popękane.

\section{Potwór}

Piątym i ostatnim z elementów wywołujących grozę jest potwór zwany Tu u n b a q, przez marynarzy nazywany również Terrorem i będący pożeraczem dusz, którego Simmons stworzył w wyniku połączenia wielu innuickich mitów o powstaniu świata i przygodach bogini morskich głębin - Sednie, a zwłaszcza o duchach tuurngait. Stworzony przez siebie mit zamieścił w powieści jako jeden z jej rozdziałów.

Dowiadujemy się z niego, że podczas wojny bogów Sedna, bogini morza, powołała do życia własnego tupilek, czyli złośliwą istotę, której zadaniem było prześladowanie i zabijanie wrogów ich stwórczyni. Ów potwór wymknął się jednak bogini spod kontroli, więc ta - z obawy o swoje bezpieczeństwo - za pomocą

${ }^{40}$ D. Simmons, op. cit., s. 454-455; brak dostępu do wersji oryginalnej. 
specjalnego zaklęcia wygnała potwora na Ziemię, na daleką północ, gdzie żyli szamani potrafiący radzić sobie ze złymi duchami. Wygnany Tuunbaq przybrał postać najgroźniejszego stworzenia, jakie spotkał na północy — białego niedźwiedzia. Pożerał dusze zwierząt, lecz szybko przekonał się, że te ludzkie są o wiele smaczniejsze. Komunikować się z Tuunbaqiem i składać mu ofiary, aby nie napadał na wioski ludzi, mogły szamańskie dzieci.

Potwór symbolizuje nieprzyjazny i obcy kulturowo dla uczestników wyprawy obszar. Sama opowieść jest straszna nawet bez obecności Tuunbaqa. Monstrum stanowi zatem raczej element uatrakcyjniający fabułę, jako że jego obecność wymusza na bohaterach odpowiednie działania. Co ciekawe, morduje on admirała Franklina - najbardziej zagorzałego zwolennika teorii, iż to zwykły niedźwiedź, na którego należy po prostu zapolować. Śmierć głównodowodzącego z łap zwierza daje pozostałym członkom załogi jasny sygnał — nikt tak naprawdę nie jest bezpieczny.

Co ważne, monstrum przez długi czas jest nieuchwytne i słabo widoczne, gdyż dzięki białej sierści łatwo wtapia się w otoczenie. $Z$ tego też względu wielu bohaterów początkowo uważa go za przerośniętego niedźwiedzia polarnego. Przez długi czas Tuunbaq jest przeciwnikiem nierozpoznanym, a o jego działalności świadczą jedynie rozczłonkowane ofiary. Kluczem do zrozumienia istoty wywoływania grozy przez Tuunbaqa mogą być słowa niemieckiego psychiatry Ernsta Jentscha, który twierdził, że

Jeden z najpewniejszych chwytów artystycznych służących do łatwego wywoływania niesamowitych oddziaływań przez opowiadanie polega na tym, że pozostawia się czytelnika w niepewności co do tego, czy w wypadku pewnej postaci ma się do czynienia z osobą czy na przykład z automatem, $\mathrm{i}$ to tak, by niepewność ta nie wchodziła bezpośrednio w ogniskową jego uwagi, tak, aby nie skłaniać czytelnika do natychmiastowego zbadania i wyjaśnienia sprawy, albowiem w ten sposób, jak już stwierdzono, łatwo zanika owo specyficzne oddziaływanie uczuciowe ${ }^{41}$.

Analogicznie rzecz ujmując, czytelnik bądź widz Terroru oraz sami bohaterowie nie wiedzą, czy Tuunbaq jest tylko niedźwiedziem, czy też istotą nadprzyrodzoną. Pod koniec powieści kwestia ta ulega wyjaśnieniu, natomiast w serialu pozostaje niedopowiedziana. Kluczowe do zrozumienia powodów, dla których Tuunbaq budzi grozę, może być pojęcie niesamowitości. Według Sigmunda Freuda niesamowitość nie jest ani niczym nowym, ani obcym, lecz czymś od dawna charakterystycznym dla życia psychicznego, co w jakiś sposób wyobcowało się z niego za sprawą procesu wyparcia ${ }^{42}$. Do wyparcia czego służy zatem odbiorcom polujący na marynarzy potwór?

W kontekście powieści potwór może zostać uznany za personifikację lęku człowieka przed nieokiełznaną potęgą natury. Tuunbaq jako niedźwiedź jest zwie-

${ }^{41}$ Cyt. za: S. Freud, Niesamowite, [w:] Pisma psychologiczne, t. 3, przeł. R. Reszke, Warszawa 1997, s. 241.

42 Ibidem.

Literatura i Kultura Popularna XXVII, Wrocław 2021

(C) for this edition by CNS 
rzęciem, na które w dodatku człowiek poluje, a zatem to on jest myśliwym, czyli katem, a zwierzyna ofiarą. Sama myśl, że może istnieć stworzenie silniejsze i sprytniejsze od człowieka, na które nie da się zapolować, pomniejsza w pewnym stopniu pozycję ludzi, którzy według Księgi Rodzaju powinni „,uczynić ziemię sobie poddaną". Potwór jest więc personifikacją wszystkich wymienionych dotąd zagrożeń, będąc jednocześnie symbolem nieokiełznanej potęgi natury, której ulegli dumni uczestnicy wyprawy admirała Franklina. Świadczy o tym jeden z opisów przedstawiający przemyślenia kapitana Croziera na temat tożsamości monstrum:

Wiedział jednak coś, z czego marynarze nie zdawali sobie jeszcze sprawy, że Diabeł, który próbował ich zabić w tym białym Królestwie Diabła, miał nie tylko postać porośniętego futrem drapieżnika, lecz był wszystkim, co ich otaczało - nieustępliwym zimnem, wszechobecnym lodem, burzami, brakiem jakiejkolwiek zwierzyny, która mogłaby służyć im za pożywienie, górami lodowymi, które wędrowały przez zamarznięte morze, nie zostawiając za sobą nawet skrawka otwartej wody, wałami lodowymi wyrastającymi znienacka z powierzchni paku, tańczącymi gwiazdami, zepsutym śmierdzącym jedzeniem w puszkach, latem, które nie nadeszło po wiośnie — wszystkim. Potwór z lodu był tylko jednym z wcieleń Diabła, który chciał ich śmierci. I chciał ich cierpienia ${ }^{43}$.

W serialu podobieństwo Tuunbaqa do niedźwiedzia polarnego jest dużo bardziej zaakcentowane. Tułów potwora bardzo mocno przypomina zwierzę, z wyjątkiem łba i łap. Jego pysk przywodzi jednak na myśl ludzką, ewentualnie diabelską twarz. Jak przyznał jeden z showrunnerów serialu — David Kajganich — składając zamówienie u projektanta tworzącego koncept Tuunbaqa — Neville’a Page’a zasugerował, że

to stworzenie powinno wyglądać prawie po prezydencku, kiedy pierwszy raz je zobaczymy, w takim sensie, że powinno wyglądać, jakby miało wielki autorytet i władzę, a jednocześnie nie mieć kłów, rogów czy świecących oczu lub innych elementów, jakie kojarzą się z monstrami $^{44}$.

Z kolei wspomniany już Page wyjaśnił, że podczas pracy nad projektem potwora chciał, aby

twarz tego niedźwiedzia ukazywała inteligencję. Potrzebowaliśmy tego, aby był straszny, ale także budzący współczucie, a mówiąc kulturowo, to musiał być Eskimos. Tak więc teraz nie chodziło już o to, żeby tylko poczuł się jak człowiek. Musi poczuć się kobiecy, mądry i eskimoski ${ }^{45}$.

Jest to rzeczywiście ciekawe, gdyż o ile bardzo łatwo można dostrzec inteligencję w oczach Tuunbaqa, które wyglądają bardziej ludzko niż zwierzęco, o tyle w stosunkowo krótkich ujęciach ukazujących głowę potwora trudno się dopatrzeć elementów kobiecych bądź inuickich. Z pewnością jednak już pierwsza z wymienionych cech przyczyniła się do tego, iż stwór wygląda przerażająco.

43 D. Simmons, op. cit., s. 167.

44 T. Bennett, Exclusive: "The Terror" Concept Designer Neville Page on Bringing the Tuunbaq to Terrifying Life, SyFy, https://bit.ly/3Bp2M8K (dostęp: 30.12.2019).

45 Ibidem. 
Interesujący jest także kształt kończyn potwora, a w konsekwencji sposób, $\mathrm{w}$ jaki się porusza. Tuunbaq przemieszcza się raz na czterech łapach, a innym razem na dwóch. O ile tylne odnóża wyglądają jak u zwierzęcia, o tyle przednie przypominają ludzkie dłonie ze szponami, które zginają się do środka. Dzięki temu może on z łatwością chwytać marynarzy i ciąć ich swoimi ostrymi pazurami, jakby był istotą posiadającą kciuki. Scena, w której doktor Goodsir ogląda rany zabitych i układa rękę, rozcapierzając palce w taki sposób, w jaki musiał zrobić to potwór, aby zadać cios, uświadamia nam jego „ludzki” charakter, a lekarzowi, że nie ma do czynienia ze zwykłym niedźwiedziem polarnym. Jak zauważa Noël Carroll:

wiele przypadków nieczystości powstaje w wyniku działania, by użyć pojęć przyjętych od Mary Douglas, pośredniości oraz sprzeczności kategorialnej. Nieczystość wynika z konfliktu między dwoma lub więcej utrwalonymi kategoriami kulturowymi. Nic więc dziwnego, że wiele $\mathrm{z}$ podstawowych sposobów tworzenia potworów ma naturę kombinatoryczną. Jedną $\mathrm{z}$ głównych struktur budulcowych jest zespolenie ${ }^{46}$.

Według Carrolla zespolenie polega zatem na tworzeniu takich postaci, które przekraczają w jakiś sposób granice utrwalonych kulturowo kategorii, takich jak: wewnątrz-zewnątrz, życie-śmierć, owad-człowiek itd. ${ }^{47}$ Postać zespolona powinna więc łączyć w sobie właściwości niepasujące do schematów kulturowych ${ }^{48}$, wywoływać kontrast między tym, co jest nam znane, a tym, czego dowiadujemy się o monstrum. Tuunbaq jest przykładem postaci zespolonej, która wywołuje strach nie tylko u odbiorców, ale też wśród bohaterów. Warto dodać, iż bestia ta nie łączy jedynie cech człowieka i niedźwiedzia. Porusza się bowiem nad wyraz prędko jak na swoją masę. Jest to widoczne w scenie, w której oficerowie uwięzieni pod pokładem Terroru przez okna swojej kabiny oglądają, jak potwór jednym szybkim susem wskakuje na pokład. Zwinność monstrum skłania do porównywania go raczej z wielkim, dzikim, białym kotem niż niedźwiedziem polarnym.

Co ważne, potwór zostaje nam pokazany w całości dopiero w połowie serialu, przy czym nawet wówczas nie jest dobrze widoczny, gdyż akcja rozgrywa się we mgle. Tak naprawdę w pełnej krasie możemy go oglądać dopiero w ostatnim odcin$\mathrm{ku}$. W pierwszych epizodach natomiast widzimy wyłącznie fragmenty potwora i to przez krótką chwilę, najczęściej nie widzimy go jednak w ogóle. O jego obecności możemy wnioskować tylko na podstawie efektów jego działań, ofiar i zniszczeń.

Szczególnie interesującym pod względem budowania nastroju grozy jest zabieg zastosowany w trzecim odcinku Terroru, kiedy to Tuunbaq atakuje admirała Franklina. Widzowie mają wówczas do czynienia ze swego rodzaju ujęciem subiektywizującym. Kamera ukazuje wleczonego po lodzie głową w dół Franklina. Obraz przestaje być statyczny, kamera porusza się w rytm kroków potwora, z którego obecności tuż poza kadrem zdajemy sobie sprawę dzięki jego rykom i sapa-

\footnotetext{
46 N. Carroll, Filozofia horroru, przeł. M. Przylipiak, Gdańsk 2004, s. 79.

47 Ibidem.

48 Ibidem.
}

Literatura i Kultura Popularna XXVII, Wrocław 2021

(C) for this edition by CNS 
niu. Chwilę potem, tuż przed wrzuceniem admirała do przerębli, widać, iż ma on uciętą nogę. Co ciekawe, w tej kluczowej dla fabuły scenie nie wiadomo tak naprawdę, czym jest stworzenie ani jak wygląda.

Innym bardzo ciekawym chwytem jest samo podejście twórców do Tuunbaqa. Jak już wspomniano, jego rola, choć podobna do tej z powieści, została znacznie okrojona. W serialu potwór również uosabia siły natury, jednak nie ma tak wielkiej mocy sprawczej jak u Simmonsa. Przypomnijmy, dużo większym zagrożeniem od potwora stają się ludzie, a zwłaszcza Cornelius Hickey.

Podobnie sytuacja wygląda w trakcie sceny balu karnawałowego, podczas którego marynarze budują wielki namiot podzielony na komnaty, z których każda ma inny kolor, co jest nawiązaniem do opowiadania Edgara Alana Poe - Maska Czerwonego Moru (1842). Jej bohater Prospero, chcąc uchronić się przed zarazą, ukrywa się w opactwie, gdzie wyprawia bal maskowy w siedmiu różnokolorowych pomieszczeniach. Pojawienie się o północy tajemniczej postaci powoduje śmierć biesiadników, w tym głównego bohatera. Nawiązanie do gotyckiej w duchu Maski Czerwonego Moru, będącej alegorią nieuchronności śmierci, jest zabiegiem celowym, albowiem marynarze, podobnie jak Prospero, próbują nieroztropnie zaklinać rzeczywistość, nie zdając sobie sprawy, iż śmierć może przyjść także podczas karnawału. W powieści Simmonsa przychodzi ona pod postacią potwora. Kiedy pijani uczestnicy karnawału śpiewają dumnie słowa brytyjskiej pieśni patriotycznej - Rule Britania ${ }^{49}$ - Tuunbaq rozpoczyna rzeź uczestników biesiady. W serialu to jednak nie potwór przyczynia się do rzezi uczestników, lecz lekarz okrętowy... który w trakcie pierwszych pięciu odcinków wydaje się uosobieniem brytyjskiego stoicyzmu. Jak się jednak okazuje, stan psychiczny doktora Stanleya nie jest dobry - medyk oblewa naftą ściany namiotu, a na koniec dokonuje aktu samospalenia. W ten sposób twórcy telewizyjnej wersji Terroru zupełnie zmieniają wydźwięk tej sceny, czyniąc samych uczestników wyprawy, razem $\mathrm{z}$ ich niestabilną psychiką, najniebezpieczniejszymi przeciwnikami.

\section{Podsumowanie}

Warto podkreślić, że zarówno powieść, jak i serial Terror są ciekawą mieszanką gatunkową oraz przykładami tak zwanego retellingu znanych wydarzeń historycznych. Mamy tu bowiem do czynienia nie tylko z elementami powieści historycznej, horroru należącego do nadrzędnej kategorii, jaką jest fantastyka, ale też mitologii.

Elementy grozy mają służyć zwróceniu uwagi na problemy współczesnego świata, jak również w interesujący sposób przybliżyć nieznane powszechnie fak-

49 Wykorzystanie akurat tej brytyjskiej pieśni w scenie mordu marynarzy wydaje się dość symbolicznym i ironicznym zabiegiem, zwłaszcza biorąc pod uwagę, że Dan Simmons pochodzi ze Stanów Zjednoczonych.

Literatura i Kultura Popularna XXVII, Wrocław 2021

(C) for this edition by CNS 
ty na temat wydarzeń historycznych. Do tego celu posłużyła autorowi technika przez zachodnich badaczy określana mianem faction, polegająca na łączeniu faktów z fikcją w celu uwiarygodnienia wykreowanych wydarzeń. Do wywołania grozy pisarz wykorzystał czynniki, które w naszej cywilizacji stanowią naturalne zagrożenie. W ten sposób, posługując się gatunkiem, jakim jest horror, stworzył uniwersalną opowieść o kruchości ludzkiego bytu i ambicji wobec potęgi natury.

Serial Terror jest z kolei interesującym przykładem adaptowania elementów grozy z powieści w obręb innego medium. Udowadnia, że odpowiednie wykorzystanie technologii i właściwe podejście do pierwowzoru pozwalają uwydatnić grozę, a jednocześnie zachować wierność oryginałowi.

\section{Bibliografia}

\section{Teksty}

Simmons D., The Terror, Little/Brown, New York 2007.

Simmons D., Terror, przeł. J. Ochab, Wydawnictwo Wesper, Czerwonak 2015.

\section{Opracowania}

Bruce T., The Case for Faction as a Potent Method for Integrating Fact and Fiction in Research, [w:] Innovations in Narrative and Metaphor - Methodologies and Practices, red. S. Farquhar, E. Fitzpatrick, University of Auckland, Auckland 2019.

Burke E., Dociekania filozoficzne o pochodzeniu naszych idei wzniosłości i piękna, przeł. P. Graff, Wydawnictwo Naukowe PWN, Warszawa 1968.

Carroll N., Filozofia horroru, przeł. M. Przylipiak, słowo/obraz terytoria, Gdańsk 2004.

Conolly O., Haydar B., The Case Against Faction, „Philosophy and Literature” 32, 2008, nr 2.

Forsyth F., Upiór Manhattanu, przeł. W. Nowakowski, Albatros, Warszawa 1999.

Freud S., Niesamowite, [w:] Pisma psychologiczne, t. 3, przeł. R. Reszke, Wydawnictwo KR, Warszawa 1997.

Gemra A., Od gotycyzmu do horroru: wilkołak, wampir i monstrum Frankensteina w wybranych utworach, Wydawnictwo Uniwersytetu Wrocławskiego, Wrocław 2008.

Herbert B., When English Meets History: Exploring the Faction Genre through Action Learning, „Literacy Learning: The Middle Years” 20, 2012, nr 3.

Kamińska M., Upiór w kamerze: zarys kulturowej historii kina grozy, Galeria Miejska Arsenał, Poznań 2016.

Kraska M., Na tropie Szakala. Gry i konwencje political fiction, Wydawnictwo Uniwersytetu Gdańskiego, Gdańsk 2003.

Kuznets L.R., Fiction, Faction, and Formula in the Regional Novels of Lois Lenski, „Children's Literature Association Quarterly" 1982.

Lanone C., Monsters on the Ice and Global Warming: From Mary Shelley and Sir John Franklin to Margaret Atwood and Dan Simmons, [w:] EcoGothic, red. A. Smith, W. Hughes, Manchester University Press, Manchester 2013. 
Leavenworth M.L., The Times of Men, Mysteries and Monsters: The Terror and Franklin's Last Expedition, [w:] Arctic Discourses, red. A. Ryall, J. Schimanski, H. Howlid Wærp, Cambridge Scholars Publishing, Newcastle upon Tyne 2010.

Olkusz K., Gotyckie światy współczesnej grozy, [w:] Światy grozy, Ośrodek Badawczy Facta Ficta, Kraków 2016.

Płonka-Syroka B., Wstęp, [w:] Groza. Społeczno-kulturowe mechanizmy kreowania emocji, red. B. Płonka-Syroka, M. Szymczak, Oficyna Wydawnicza Arboretum, Wrocław 2010.

Rachlewicz G., Postowie, [w:] D. Simmons, Terror, przeł. J. Ochab, Wydawnictwo Wesper, Czerwonak 2015.

Syska R., Thriller jako gatunek, [w:] Wokót kina gatunków, red. K. Loska, Rabid, Kraków 2001.

Żyto K., Strategie labiryntowe w filmie fikcji, Wydawnictwo Uniwersytetu Łódzkiego, Łódź 2010.

\title{
Źródła internetowe
}

Bennett T., Exclusive: "The Terror" Concept Designer Neville Page on Bringing the Tuunbaq to Terrifying Life, SyFy, https://bit.ly/3Bp2M8K (dostęp: 30.12.2019).

Erebus and Terror - John Franklin Search of the North-West Passage, https://bit.ly/3BlwWd3 (dostęp: 30.12.2019).

Franklin, Sir John, [hasło w:] Dictionary of Canadian Biography, https://bit.ly/3iwcsWq (dostęp: 30.12.2019).

Han K., The Terror, TV's Scariest New Series, Isn't Really a Horror Story, „Vanity Fair”, https:// bit.ly/3wSPjm8 (dostęp: 30.12.2019).

HMS Terror ,zamrożony w czasie”. Stynny okręt zostat zbadany, TVN24, https://bit.ly/2W206hp (dostęp: 30.12.2019).

Kowalski K., Jak zginęli członkowie polarnej ekspedycji Johna Franklina, „Rzeczpospolita”, https://bit.ly/3wMq31b (dostęp: 30.12.2019).

Travers B., The Terror' Was Not Shot Outside - It's Almost Entirely Visual Effects, IndieWire, https://bit.ly/2VW4yOx (dostęp: 30.12.2019).

Why Tobias Menzies and Jared Harris Always Do Historic Movies?, YouTube, https://bit.ly/3hNah1I (dostęp: 30.12.2019).

\section{Filmografia}

Marsjanin (The Martian), reż. R. Scott, USA-Wielka Brytania 2015.

Terror (The Terror), reż. T. Mielants, E. Berger, S. Mimica-Gezzan, scen. D. Kajganich, H. Soo, AMC, USA 2018.

\section{How to Evoke Atmosphere of Horror? A Comparative Analysis of the Novel and the TV Series Terror}

\author{
Summary
}

The polar expedition commanded by Sir John Franklin, which disappeared in the Arctic archipelago between 1845 and 1847, is still one of the most mysterious disasters in the history of the Royal Navy and the British Empire. Scientists are still not sure what happened to the 129 sailors. The events have become a basis for a horror story Terror written by Dan Simmons and adapted 
as a TV series by Ridley Scott. Both of them are interesting cases of genre mixtures. But the clue of the article is to analyze the tools both the book and the TV series use to induce fear among the audience. Firstly, the author focused on historical background which allows introducing a storytelling strategy known as faction. Secondly, the article indicates stylistic means of communication that were used to evoke the atmosphere of horror, sometimes different in the case of literature and audio-visual arts. 